\title{
Inquiry-Based Learning in Business Administration
}

\author{
Georg Müller-Christ
}

In many cases, it is assumed that research-oriented teaching means imparting existing research designs to students or allowing them to participate therein. This article puts forth the idea that new research designs can be developed through the involvement of students in the research process.

\subsection{Teaching-Learning Situation in Business Administration}

What has changed in the academic process of transferring knowledge that has led to students suddenly being transformed into "young researchers"? They should participate in and promote the process of creating knowledge. But what existed prior to this? And what didactic conditions (still) exist in business administration?

Prior to this change of paradigm, a course of study all the way up to the higher semesters consisted of individual processes of adopting existing bodies of knowledge. The advantage of this kind of academization, and thus of imparting education as a higher problem-solving ability, is its verifiability: Students who have acquired the given body of knowledge at a level that instructors consider high receive good grades. Those who only partially master the wealth of knowledge receive bad grades. Business administration has always been a discipline where the body of knowledge consists of explicative and technological statements. These quasi-normative statements dictate which actions are beneficial to corporate success. For business research, this functional perspective ("what works is true") means looking for generalizable cause-and-effect relationships in practice

\footnotetext{
G. Müller-Christ, Prof. Dr. ( $ه)$

Universität Bremen, Fachbereich Wirtschaftswissenschaft, Fachgebiet Nachhaltiges Management, Bremen, Germany e-mail: gmc@uni-bremen.de
} 
(empirical research) or deducing cause-and-effect relationships from concepts (theoretical research).

The challenge for business administration now lies in the fact that it is permanently increasing the body of knowledge in all its functional areas (procurement, production, marketing, human resource management, etc.) in terms of explicative and technological statements, thus making the "mountain of knowledge" that the students are supposed to climb ever steeper. Acquiring that knowledge then demands the memorization of large bodies of knowledge, which leads students to have an attitude of passive consumption, then apply the ethos of their own discipline during learning as well: Achieving the prescribed or self-imposed goal efficiently, which is to say with the least possible effort, seems to be the prevailing maxim of action.

Research-oriented teaching requires a higher emotional, mental and temporal effort on the part of both parties. While the students are at least formally protected from excessive strain due to the workload concept, instructors face the risk of an unmanageable support effort, especially when it comes to modules with larger numbers of attendees. In seminars with a manageable number of participants, the well-known didactic forms of researchoriented learning such as roleplays, simulation games, case studies and project-based studies have long been used in business administration. Nonetheless, according to empiricism, these forms are primarily used with the objective of discovery learning. Research in the sense of discovery means that students themselves discover existing bodies of knowledge in alternative, didactic ways. This applies in particular to roleplaying and business games as well as case studies, criticism of which Henry Mintzberg (2004) dealt with intensively. Students are encouraged to use inductive processes, where logical thinking leads them to conclusions that instructors have long known and that relate to context-free cases from the past (Mintzberg 2004). Project-based studies initially have an open design and can be considered a basic condition for different motives between a targeted transfer of knowledge and freely chosen research into a new topic.

\subsection{How Does Something New Become a Part of Business Administration? Different Research Designs}

Theories are considered statement systems, which can contain numerous propositions and hypotheses about correlations. Finding new hypotheses can also be the goal of researchoriented learning. It makes a difference whether research is conducted within the context of justification or of discovery, especially when it comes to teaching. In the context of justification, hypotheses are usually subjected to an empirical examination, while in the context of discovery, new hypotheses are obtained. The search for how something new comes into the world implies research within the context of discovery, and that this takes place with new forms of knowledge. In business administration, known paths of knowledge are likewise deduction and induction. Less well-known is abduction; intuition is 
employed even less frequently. These four forms of knowledge acquisition are briefly explained in terms of their ability to bring something new into the world (cf. Fig. 24.1).

\subsubsection{Distinction Between Fundamental Paths of Knowledge}

The discussion concerning the fundamental paths of knowledge is being pursued with continuing intensity in cognitive science and the philosophy of science. These can be distilled into the following distinction.

Deduction: Deduction is the form of knowledge in the context of justification. It consists of drawing specific propositions from general propositions. If, for example, the premise applies that when there is an increase in the production volume, the costs also increase (general proposition), then observing an increase in the production quantity leads to the conclusion that costs are also rising. Rising costs can then be determined empirically. Deduction cannot really generate new insights, only propagate existing ones (Brühl 2015).

Induction: This method is frequently used in business administration. Practical corporate behavior should be explained by showing the correlation between a case and, ultimately, corporate success (in the form of profit). Best practice concepts have been and still are very popular in management research since the release of the bestseller In Search of

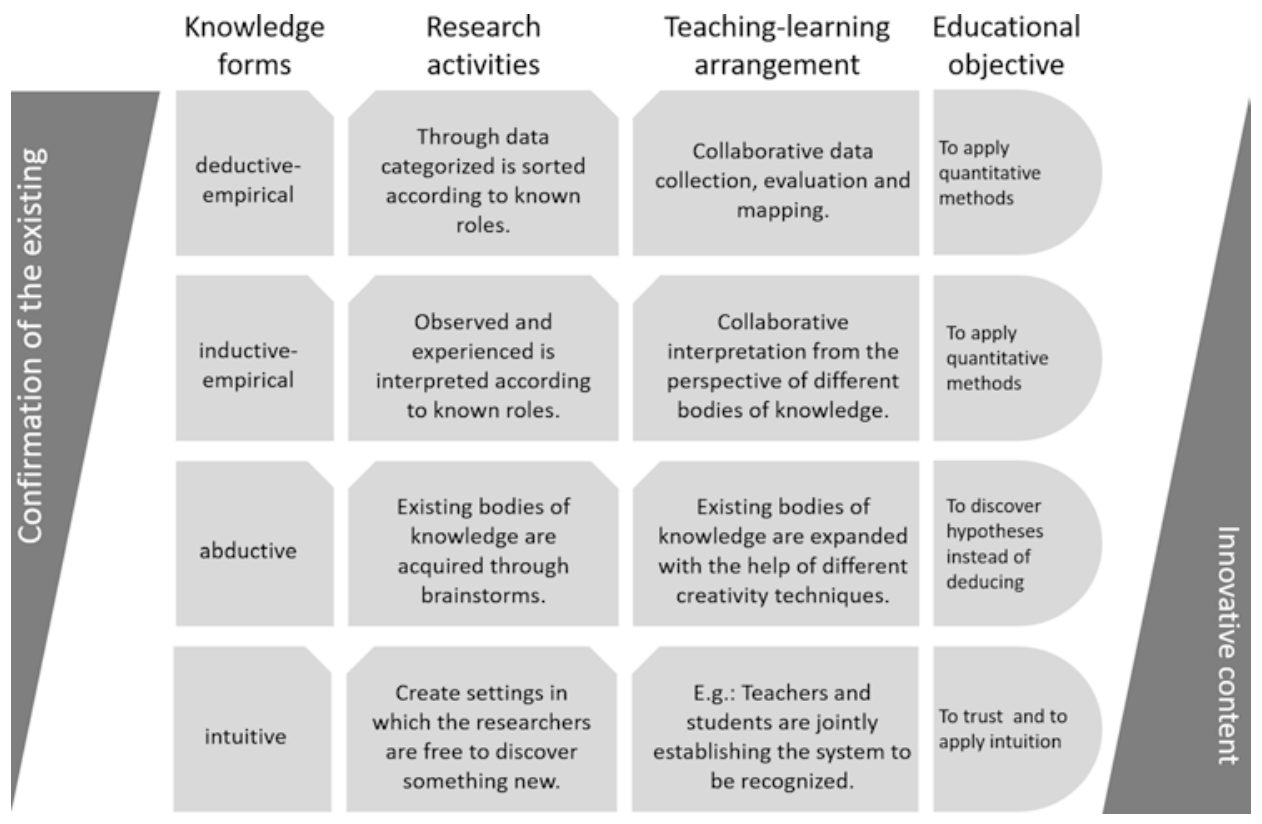

Fig. 24.1 Matrix of the cognitive processes in research-oriented learning. (Source: Author's representation) 
Excellence (Peters and Waterman 1984). New insights usually only lead to imitation and thus the duplication of existing patterns of action.

Abduction: In terms of formal logic, the problem that triggers abduction is the following: There is only one event known, and no law and no constraint from which anything can be logically concluded. Creativity is therefore required in order to deduce a generalizable hypothesis from an event. For Charles Sanders Peirce, who introduced and described abduction, it is a lightning-fast insight that only occurs upon conclusion of a process when faced with a problem and based on knowledge of the facts, and that tends to be hampered by logical rules of reasoning (Reichertz 2013).

Intuition: Intuition in its narrower sense is inspiration, and thus the development and experience of knowledge that was not previously present in the person seeking or researching. These intuitive flashes of inspiration, gut decisions or ideas can barely be rationally explained, and their formation and origin can hardly be substantiated. Intuition does not simply encounter people unprepared in everyday life. Intuition is present in the moment in which seekers or researchers concentrate fully on a topic or a task and get into a "flow." In other words: Intuition is most likely to come to the prepared mind.

The distinctions made in Fig. 24.1 are of a categorizing nature. In the practical research process, different types of cognition alternate. Even with purely deductive-empirical research, new insights can arise through abduction or intuition: the view of the data suddenly gives rise to an insight that was not there before. Some explanations as to the teaching-learning arrangements for research-oriented learning in this research design will be provided below, based on the simplification that work tends to be deductive in quantitative empirical research, inductive in qualitative social research, and abductive and intuitive in systemic research (cf. for more detail Müller-Christ 2015).

\subsubsection{Research-Oriented Teaching Design}

\section{Research-oriented teaching design I: Technological statements through quantitative research}

This research-oriented teaching design best fits the notion that research-oriented learning entails the entire research process. Students should have the opportunity to get to know a research process from the definition of the research question, the derivation of hypotheses, the translation into an empirical design, data collection, data analysis and interpretation to publication (Huber et al. 2013). It is possible to become familiar with the process in a lecture, but true rapprochement only occurs when performing the process oneself. Such processes are shaped in teaching within the framework of project modules and theses.

The challenge for instructors lies in communicating the methods in this field of research. This can be prepared by lectures, but a "dry run" of this sort does not mean that students can recognize the methodological challenges in their research process and cope well. Supporting students is therefore very costly in terms of time and personnel. It is only possible to get through such a process over the course of a semester if the questions are very 
limited. Until now, it has been difficult for students to obtain empirical survey data; however, online surveys facilitate and reduce the costs associated with access to representative data volumes considerably.

Certainly there are areas of business administration that cling to the old belief that only quantitative research is scientific, because it has standardized, validated procedures that allow for generalizable statements. This attitude is particularly obvious when international publications are sought as a result of research. The results of quantitative research, especially within the context of justifying hypotheses, are easier to publish than the results of qualitative research in the context of discovery because of their international comprehensibility.

\section{Research-oriented teaching design II: Hermeneutic statements through qualitative research}

Hermeneutics is the method of understanding recognition of life situations. Anyone who proceeds in a hermeneutic way would like to understand and explain interdependencies and perhaps even contexts of meaning such that they can understand and relate to them. This reconstruction of social occurrences utilizes methods of social research by means of observation, interviews or case analyses. If students participate in this process of social reconstruction in a research-oriented teaching-learning arrangement, they usually learn how to conduct and evaluate qualitative surveys with interviews or observations within the context of project papers and final papers. Since the time and money for extensive surveys are usually too limited, a few interviews are subjected to an evaluation using content analysis and new hypotheses are then derived inductively. Often, there is no capacity left to clarify whether the found hypotheses are really new or have been dealt with in literature for some time, or perhaps even already discarded. Perhaps this is not so relevant, however, since research-oriented learning is more likely to enable students to shape the process of discovery and reasoning according to scientific criteria.

The crucial bottleneck for students in this research-oriented teaching design is access to suitable interlocutors within the specified period of project work. In my experience, research topics related to leadership issues are very popular with students. The big challenge for the instructors is the distinction between the positive effect of discovery learning and the actual finding of a new hypothesis. Interpretation as the assignment of meaning is easier for the instructors, who have more substantial background experience than the students. Students are presumably more likely to discover something new for themselves.

\section{Research-oriented teaching design III: Generating hypotheses using system constellations}

The system constellation method is a method of acquiring knowledge in which people are placed spatially as elements of a system. They visualize the system by showing the relationships of the elements to one another through their distance and their line of gaze. System constellations work using transverbal spatial language: People are able to 
understand the system embodied by proxies in spatial relationship in a relatively similar way without the need for verbal communication. Representatives for the elements arrive at a representative perception of the state of the elements that they represent, and can often clearly verbally communicate how changes in the system affect their perceptions. In constellations, it is very important that the representatives only pay attention to their physical condition and track the changes, but do not reflect thereon. Thinking processes can prevent the detection and perception of differences. They can be avoided by placing the representatives such that they are concealed so they do not know which element they represent. The silent assignment of the representative, for example, by the constellation facilitator appears to position the representative perception as well. For the sake of brevity, the method cannot be discussed in detail. However, there is already a considerable body of introductions to and reflections on the method in the organizational literature associated with consultation (e.g. Rosselet 2012).

The teaching concept using the system constellation method is still new compared to the first two teaching designs and is used by only a few teachers (Müller-Christ 2015). It is important to mention right from the start that the use of system constellations requires the guidance of an organizational constellation facilitator. The representative perception of the representatives must be enticed and supported sensitively, and students' options must be taken into account. The use of system constellations should be systematically taught and practiced; however, it can be learned quickly. The system associated with this research-oriented teaching design is presented by Müller-Christ (in press) based on a sample constellation. The question of how constellations can be evaluated as innovative methods of qualitative social research is also addressed therein.

\subsection{The New Role of Instructions in a Systematic, Research- Oriented Teaching-Learning Process}

The research-oriented teaching design III changes the entire teaching-learning process with its systemic perspective. In the first two designs, instructors act by dint of their substantive superiority in terms of content: They have more experience and more knowledge in applying quantitative and qualitative empirical methods, and presumably they learn very little as a result of student findings. In the systemic perspective of the researchoriented teaching design III, instructors become a learning guide, because something new is sought, in collaboration, which the instructor did not know before either. Therefore what is at issue is the creation of a teaching-learning setting in which a space of exploration, discovery and wonder (Scharmer and Käufer 2014) is created with the students, a space where they can seek something new together. In order to do so, instructors must step down from their infallible position and learn to view that which is familiar to them in a new way with the students. This repositioning of instructors and learners is a challenge, especially in business administration, because those who are actually teaching become learners again, and those who hitherto have been mere consumers of bodies of knowledge actively 
appropriate their own learning process. If both parties agree on the format, a creative space of joint research can emerge, which is a lot of fun for all those involved, and which allows astonishment and new questions to arise. Perhaps business administration and management theory is just waiting for incentives of this kind? (Box 24.1)

\section{Box 24.1: Collaborative Research in Business School: Benefits from the Research Group Model. (Extracted from Bartkus et al. 2010)}

Although business students account for approximately $22 \%$ of undergraduate degrees in the U.S., business is one discipline that has been largely absent from the discussion about undergraduate research. One of us (Bartkus 2007) has noted, for example, that business projects accounted for fewer than $3 \%$ of the presentations at the National Conference on Undergraduate Research in 2007 and that business faculty make up less than $1 \%$ of the members of the Council on Undergraduate Research.

Given the importance of undergraduate research and the under-representation from colleges and schools of business, Bartkus (2007) introduced the Research Group model to encourage greater involvement by faculty and students. Since it began to evolve in 2004, the Research Group in the Jon M. Huntsman School of Business at Utah State University has continued to evolve and provide benefits to both students and faculty members. Here we describe the structure, benefits, assessments, and implications for future development of the model.

\section{Research Group Model: An Overview}

The model, developed at the Huntsman School, summarizes its mission this way:

The Research GroupTM is a not-for-profit consortium of business and university scholars, corporate leaders, and qualified undergraduate students dedicated to the advancement of high quality research experiences. Its mission is to provide students the opportunity to develop core competencies in the use of the scientific method as it relates to business and public policy issues. In doing so, students become better prepared for success in graduate school and their chosen careers. The guiding motto of The Research Group is "Research that Matters." (Bartkus 2007, p. 8)

As a consortium, the administrative structure of the model is relatively straightforward. Students enter the program as "associates" (as opposed to students) and work under the guidance of "partners" (as opposed to faculty). These titles are intended to reflect the notion that students are gaining relevant work experience, which has been cited as an important consideration for employment and admission to graduate business programs.

To further ensure that the experience is relevant, the model encourages students to publish in peer-reviewed publications and/or present at scholarly research forums such as at the National Conference on Undergraduate Research. Students who 
Box 24.1: (continued)

succeed in those areas become eligible for promotion to the "senior associate" level where they continue their research and also mentor incoming associates.

Students and faculty members are also required to obtain training and certification in human-subjects research through the university's institutional review board. This certification is the national standard and provides students with a bona fide credential. Additionally, students can receive awards from the Huntsman School in recognition of their research scholarship (e.g. annual Awards for Scholarly Merit). The school also designates one deserving student each year as the outstanding undergraduate researcher. In these ways, students gain both relevant experience and documented recognition of research productivity.

In sum, the model takes the traditional educational concept of undergraduate research and administers it under the auspices of a professional research organization. The result? Both students and faculty develop a greater sense of ownership and pride in the program.

\section{Benefits for Students}

The research group has developed five new initiatives specifically designed to provide benefits for our students:

1. The Consumer Outlook is an online survey-research program, from which participating students gain experience in questionnaire design, sampling, data collection, analysis, and reporting. The resultant research is intended to be published in a peer reviewed outlet and/or presented at a research forum.

2. Deli-Nation.Com is an online publication that reports on events in the restaurant industry. Students work as editors, staff reporters, writers, Web masters, and video producers to develop and operate this social-media site within the business school.

3. The Research Group Quarterly is an online, open-access journal dedicated to publishing collaborative business research, interviews with business leaders and scholars, and book reviews. Students serve on the editorial board, review articles, and manage other administrative issues related to the operation of a publication.

4. Opportunities for engagement with other business-school programs provide students with mutual support and create additional research synergy.

5. Opportunities to engage with corporate entities and issues expand students' experiences. Corporate engagement occurs when an external organization collaborates with the business school.

Each of these initiatives is intended to further enhance a student's critical thinking and communications skills through real-world applications and involvement with a faculty mentor. 


\section{References}

Bartkus, K. R. (2007). Fostering Student/Faculty Collaborations Through the Research Group Model: An Application to Business Schools. CUR Quarterly, 28(2), 6-10.

Bartkus, K. R./Olsen, D./Mills, R. J./Hills, S. B. (2010). Collaborative Research in Business School: Benefits from the Research Group Modell. CUR Focus on the web, 31(1), 5-8.

Brühl, R. (2015). Wie Wissenschaft Wissen schafft. Konstanz: UTB-Verlag.

Huber, L., Kröger, M./Schelhowe, H. (Hrsg.). (2013). Forschendes Lernen als Profilmerkmal einer Universität. Beispiele aus der Universität Bremen. Bielefeld: UniversitätsVerlagWebler.

Mintzberg, H. (2004). Manager statt MBAs. Eine kritische Analyse. Frankfurt, New York: Campus Verlag.

Müller-Christ, G. (2015). Nachhaltiges Management: Systemisch(er) Forschen und Lehren für eine gelebte Transdisziplinarität. In W. Leal Filho (Hrsg.), Forschung für Nachhaltigkeit an deutschen Hochschulen (S. 97-115). Wiesbaden: Springer Spektrum.

Müller-Christ, G. (im Druck). Forschungsorientierte Lehre in der Betriebswirtschaftslehre mit Systemaufstellungen. In J. Lehmann/H.A. Mieg (Hrsg.). Forschendes Lernen: Ein Praxisbuch. Potsdam: Verlag der Fachhochschule Potsdam.

Peters, T. J./Waterman, R.H. (1984). Auf der Suche nach Spitzenleistungen. Landsberg: Verlag Moderne Industrie.

Reichertz, J. (2013). Die Abduktion in der qualitativen Sozialforschung. Über die Entdeckung des Neuen (2. Aufl.). Wiesbaden: Springer Verlag.

Rosselet, C. (2012). Andersherum zur Lösung. Die Organisationsaufstellung als Verfahren der intuitiven Entscheidungsfindung. Zürich: Versus Verlag.

Scharmer, C.O./Käufer, K. (2014). Von der Zukunft her führen. Theorie U in der Praxis. Heidelberg: Carl-Auer Verlag.

Open Access This chapter is licensed under the terms of the Creative Commons AttributionNonCommercial-NoDerivatives 4.0 International License (http://creativecommons.org/licenses/bync-nd/4.0/), which permits any noncommercial use, sharing, distribution and reproduction in any medium or format, as long as you give appropriate credit to the original author(s) and the source, provide a link to the Creative Commons licence and indicate if you modified the licensed material. You do not have permission under this license to share adapted material derived from this chapter or parts of it.

The images or other third party material in this chapter are included in the chapter's Creative Commons licence, unless indicated otherwise in a credit line to the material. If material is not included in the chapter's Creative Commons licence and your intended use is not permitted by statutory regulation or exceeds the permitted use, you will need to obtain permission directly from the copyright holder.

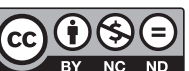

